\title{
Penentuan Mutu Buah Pepaya California (Carica Papaya L.) Menggunakan Fuzzy Mamdani
}

\author{
Muhammad Ezar Al Rivan ${ }^{1 *)}$ and Jessica Suherman ${ }^{2)}$ \\ ${ }^{1,2)}$ Program Studi Teknik Informatika, STMIK Global Informatika MDP, Indonesia \\ Corresponding Email: ${ }^{*}$ meedzhar@mdp.ac.id
}

\begin{abstract}
Papaya (Carica papaya, L.) is a fruit that has good nutritional content for health so that it has a high selling value and is made a business commodity. One variety of papaya fruit that is currently favored by all people, namely the California papaya fruit. Determination of the quality of California papaya fruit can be measured by size, color, and defect. This study raises the topic of determining the quality of California papaya fruit using fuzzy-Mamdani with input variables in the form of major axis, minor axis, red, green, and defect variables along with the output in the form of the results of determining the quality of California papaya fruit. Based on testing that has been done using 108 fuzzy rules, the validity of the results obtained states that the level of accuracy of the research using defuzzification of the Centroid, Bisector and Means of Maximum methods by $75 \%$, while the level of research accuracy using the defuzzification of Largest of Maximum and Smallest of Maximum methods by $\mathbf{7 0 \%}$
\end{abstract}

Key words : Papaya, fuzzy, Mamdani, quality

\section{Pendahuluan}

Pepaya (Carica papaya, L) merupakan tanaman yang berasal dari daerah Amerika Tengah dan tersebar luas di Pasifik Selatan dan daerah tropis lainnya. Pepaya dapat tumbuh di daerah basah dan kering mulai dari dataran rendah maupun dataran tinggi, terutama di daerah tropis. Terdapat kandungan zat-zat dan nilai gizi dalam buah pepaya yang diperlukan bagi tubuh, sehingga buah pepaya memiliki nilai jual yang tinggi untuk dijadikan komoditas bisnis [1]. Salah satu varietas buah pepaya yang saat ini digemari oleh semua kalangan masyarakat, yaitu buah pepaya California. Buah pepaya California merupakan hasil pemuliaan yang dilakukan oleh Pusat Kajian Buah Tropika (PKBT)-IPB yang disebut dengan IPB 9. Pepaya California merupakan jenis pepaya yang memiliki keunggulan antara lain, buahnya tidak terlalu besar dengan ukuran antara 0,8-2 kg/buah, berkulit tebal, halus dan mengkilat, berbentuk lonjong, buah matangnya berwarna kuning, rasanya manis, dan daging buahnya kenyal [2]

Model fuzzy yang merupakan suatu sistem yang dibangun dengan definisi, cara kerja, dan deskripsi yang jelas berdasarkan teori logika fuzzy dan memiliki beberapa proses seperti aturan fuzzy, inferensi, fuzifikasi, defuzifkasi mampu menangani ketidakjelasan dan ketidakpastian dari variabel-variabel yang digunakan dalam penentuan buah pepaya. Logika fuzzy (fuzzy logic) adalah peningkatan dari logika Boolean yang berhadapan dengan konsep kebenaran sebagian yang diperkenalkan oleh Lotfi Zadeh dari Universitas California, Berkeley pada 1965 [3]. Diperlukan juga sebuah pengolahan citra digital, yang mana citra terserbut merupakan gambar diam (foto) maupun gambar bergerak (yang berasal dari webcam), dan digital yang dimaksud adalah pengolahan citra atau gambar dilakukan secara digital menggunakan komputer. Pengolahan citra digital merupakan bidang ilmu yang mempelajari bagaimana suatu citra itu diolah, dibentuk, dan dianalisis agar dapat menghasilkan informasi yang dapat dipahami oleh manusia [4].

Penentuan kualitas buah pepaya telah dilakukan pada penelitian [5] dan [6]. Pada penelitian tersebut kualitas ditentukan dengan menggunakan Fuzzy C-Means. Selain itu pada penelitian [7] terkait dengan penentuan status gizi dan kebutuhan kalori menggunakan fuzzy. Pada penelitian [8] fuzzy juga digunakan untuk menentukan kualitas minyak. Pada penelitian [9] dilakukan menggunakan fuzzy. Pada penelitian tersebut menggunakan warna sebagai penentu kualitas dan fuzzy sebagai pengklasifikasi.

Pada penelitian [10] fuzzy digunakan untuk menentukan pemilihan kendaraan bemotor. Pada penelitian [11] menggunakan kematangan ukuran dan bercak untuk menentukan kualitas mangga. Pada penelitian [12] melakukan penentuan kualitas juga menggunakan fuzzy dengan variabel ukuran dan cacat. Fuzzy juga digunakan untuk menentukan kualitas ikan tawar seperti pada penelitian [13]. Pada penelitian yang dilakukan oleh [14] yaitu penentuan kualitas jambu biji merah juga menggunakan fuzzy.

Pada penelitian sebelumnya penentuan pepaya hanya ditentukan per satu kriteria seperti warna saja, lalu berdasarkan ukuran dan bercak kemudian berdasarkan ukuran dan cacat. Pada penelitian ini kriteria yang digunakan yaitu warna, ukuran dan cacat. Warna yang digunakan yaitu red dan green. Untuk ukuran yang digunakan yaitu mayor axis merupakan panjang buah dan minor axis merupakan lebar buah. Untuk kecacatan dihitung dengan menentukan banyak daerah yang cacat pada pepaya. Penentuan kualitas pepaya belum dilakukan secara menyeluruh. Adapun tujuan penelitian ini untuk mengukur kualitas pepaya secara keseluruhan berdasarkan kriteria warna, ukuran dan cacat.

\section{Metodologi}

\section{A. Identifikasi Masalah}

Pada tahap ini, penelitian dimulai dengan melakukan identifikasi masalah untuk memahami topik-topik 
mengenai penentuan mutu pepaya California dengan menggunakan metode Fuzzy-Mamdani.

\section{B. Studi Literatur}

Pada tahap ini,dilakukan studi literatur dengan mencari hasil penelitian dan referensi yang relevan yang berhubungkan dengan Fuzzy-Mamdani dan berbagai metode lainnya dalam menentukan kualitas buah pepaya.

\section{Pengumpulan Data}

Pada tahap ini, penulis melakukan pengumpulan data menggunakan dataset berupa gambar buah pepaya. Satu buah pepaya California diambil dari tiga sisi, yaitu depan, belakang, dan sampingnya, yang totalnya ada 20. Contoh citra pepaya dapat dilihat pada Gambar 1.

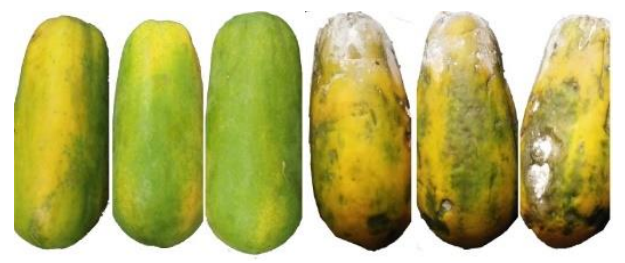

Gambar 1. Citra Pepaya

\section{Perancangan Sistem}

Pada tahap ini dilakukan sebuah perancangan sistem untuk penelitian mengenai mutu buah pepaya seperti pada Gambar 2.

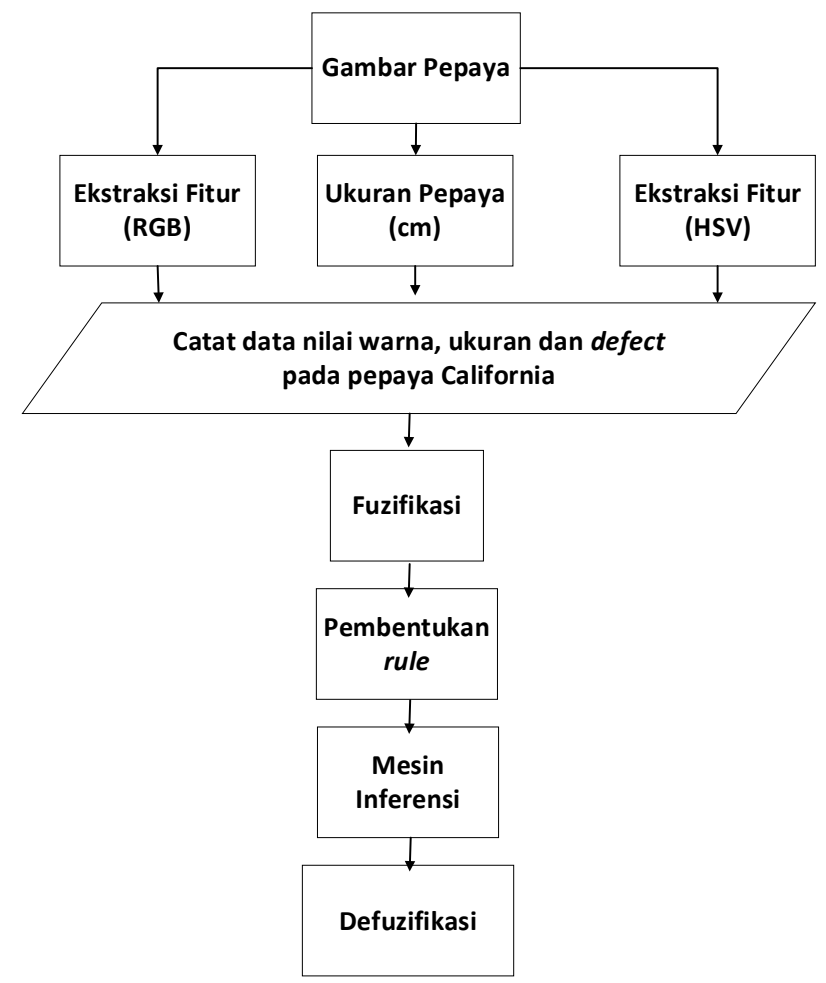

Gambar 2. Perancangan Sistem Klasifikasi Pepaya

1. Terdapat lima variabel input pada penelitian ini, yaitu red, green, mayor axis, minor axis, dan, defect.

2. Untuk mencari nilai warna red dan green dapat dilakukan dengan cara membaca citra pepaya yang dibuat melalui fungsi imread, lalu mencari nilai rata-rata dari red dan green.

3. Untuk mencari ukuran pepaya, digunakan mayor axis dan minor axis sehingga mendapatkan ukuran dalam satuan piksel. Mayor axis sebagai panjang buah dan minor axis sebagai lebar buah. Satuan piksel kemudian diubah kedalam satuan Centimeter $(\mathrm{cm})$. Gambar dapat dilihat pada Gambar 3.

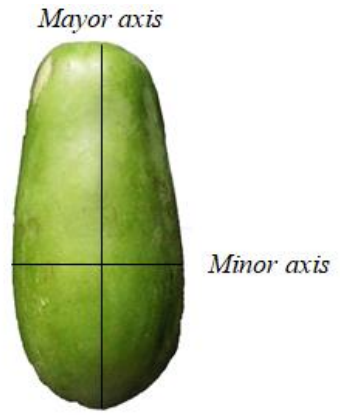

Gambar 3. Mayor Axis dan Minor Axis Citra Pepaya

4. Untuk mencari nilai defect, maka citra pepaya California akan diekstrasi fitur dari RGB ke HSV, grayscale, dan black and white (hitam dan putih). Maka, didapatlah besar nilai hitam dan putih, yang mana warna putih merupakan bagian yang cacat atau busuk dan hitam merupakan bagian yang bagus. Berdasarkan nilai tersebut, maka dapat dihitung persentase kecacatan (defect) pada citra buah pepaya dengan rumus sebagai berikut:

$\operatorname{defect}(\%)=\frac{\text { jumlah white }}{\text { jumlah white }+ \text { jumlah black }} \times 100$

5. Nilai yang didapatkan dari nomor 2, 3, dan 4 akan digunakan pada Fuzzy-Mamdani

6. Lanjut ke tahap fuzzifikasi berdasarkan kriteria dari penelitian ini, yaitu ada 5 variabel input dan 1 variabel output yaitu:

a. Mayor axis dibagi menjadi 2 himpunan: pendek, panjang.

Fungsi Keanggotaan :

$$
\begin{gathered}
\mu \text { Pendek }(\mathrm{a})=\left\{\begin{array}{c}
1 ; x \leq 10 \\
\frac{20-x}{20-10} ; 10 \leq x \leq 20 \\
0 ; x \geq 20
\end{array}\right. \\
\mu \text { Panjang (a) }=\left\{\begin{array}{c}
0 ; x \leq 15 \\
\frac{x-15}{30-15} ; 15 \leq x \leq 30 \\
1 ; x \geq 30
\end{array}\right.
\end{gathered}
$$

b. Minor axis dibagi menjadi 2 himpunan: pendek, panjang.

Fungsi Keanggotaan : $\mu$ Pendek $(b)=$

$\left\{\begin{array}{l}1 ; x \leq 5 \\ \frac{10-x}{10-5} ; 5 \leq x \leq 10 \\ 0 ; x \geq 10\end{array}\right.$

$\mu$ Panjang $(b)=\left\{\begin{array}{c}0 ; x \leq 9 \\ \frac{x-9}{12-9} ; 9 \leq x \leq 12 \\ 1 ; x \geq 12\end{array}\right.$

c. Defect dibagi menjadi 3 himpunan: sedikit, 
sedang, banyak.

Fungsi Keanggotaan :

$\mu$ Sedikit $(c)=\left\{\begin{array}{c}1 ; x \leq 10 \\ \frac{25-x}{25-10} ; 10 \leq x \leq 25 \\ 0 ; x \geq 25\end{array}\right.$

$\mu$ Sedang $(c)=\left\{\begin{array}{l}0 ; x \leq 20 \text { atau } x \geq 60 \\ \frac{x-20}{40-20} ; 20 \leq x \leq 40 \\ \frac{60-x}{60-40} ; 40 \leq x \leq 60\end{array}\right.$

$\mu$ Banyak $(c)=\left\{\begin{array}{c}0 ; x \leq 55 \\ \frac{x-55}{80-55} ; 55 \leq x \leq 80 \\ 1 ; x \geq 80\end{array}\right.$

d. Red dibagi menjadi 3 himpunan: sedikit, sedang, dominan.

Fungsi Keanggotaan :

$\mu$ Sedikit $(\mathrm{d})=\left\{\begin{array}{c}1 ; \mathrm{x} \leq 80 \\ \frac{120-\mathrm{x}}{120-80} ; 80 \leq \mathrm{x} \leq 120 \\ 0 ; \mathrm{x} \geq 120\end{array}\right.$

$\mu$ Sedang $(d)=\left\{\begin{array}{l}0 ; x \leq 110 \text { atau } x \geq 170 \\ \frac{x-110}{140-110} ; 110 \leq x \leq 140 \\ \frac{170-x}{170-140} ; 140 \leq x \leq 170\end{array}\right.$

$\mu$ Dominan $(d)=\left\{\begin{array}{c}0 ; x \leq 160 \\ \frac{x-160}{200-160} ; 160 \leq x \leq 200 \\ 1 ; x \geq 200\end{array}\right.$

e. Green dibagi menjadi 3 himpunan: sedikit, sedang, dominan.

Fungsi Keanggotaan :

$\mu$ Sedikit $(\mathrm{e})=\left\{\begin{aligned} & 1 ; \mathrm{x} \leq 100 \\ & \frac{160-\mathrm{x}}{160-100} ; 100 \leq \mathrm{x} \leq 160 \\ & 0 ; \mathrm{x} \geq 160\end{aligned}\right.$

$\mu$ Sedang $(\mathrm{e})=\left\{\begin{array}{l}0 ; \mathrm{x} \leq 150 \text { atau } \mathrm{x} \geq 190 \\ \frac{\mathrm{x}-150}{170-150} ; 150 \leq \mathrm{x} \leq 170 \\ \frac{190-\mathrm{x}}{190-170} ; 165 \leq \mathrm{x} \leq 190\end{array}\right.$

$\mu \operatorname{Dominan}(e)=\left\{\begin{array}{c}0 ; \mathrm{x} \leq 210 \\ \frac{\mathrm{x}-180}{210-180} ; 180 \leq \mathrm{x} \leq 210 \\ 1 ; \mathrm{x} \geq 210\end{array}\right.$

f. Hasil penentuan mutu yang dibagi menjadi 3 himpunan: jelek, sedang, dan bagus.

Fungsi Keanggotaan :

$\operatorname{\mu Jelek}(\mathrm{z})=\left\{\begin{array}{c}1 ; \mathrm{x} \leq 1 \\ \frac{3-\mathrm{x}}{3-1} ; 1 \leq \mathrm{x} \leq 3 \\ 0 ; \mathrm{x} \geq 3\end{array}\right.$

$\mu$ Sedang $(\mathrm{z})=\left\{\begin{aligned} 0 ; \mathrm{x} \leq 3 \text { atau } \mathrm{x} \geq 7 \\ \frac{\mathrm{x}-3}{5-3} ; 3 \leq \mathrm{x} \leq 5 \\ \frac{7-\mathrm{x}}{7-5} ; 5 \leq \mathrm{x} \leq 7\end{aligned}\right.$

$$
\mu \operatorname{Bagus}(\mathrm{z})=\left\{\begin{array}{c}
0 ; \mathrm{x} \leq 9 \\
\frac{\mathrm{x}-7}{9-7} ; 7 \leq \mathrm{x} \leq 9 \\
1 ; \mathrm{x} \geq 9
\end{array}\right.
$$

Pada tahap ini, dilakukan pembentukan fungsi keanggotaan masing-masing variabel.

7. Lanjut ke pembentukan rule atau aturan fuzzy.

8. Lanjut ke mesin inferensi dengan penerapan fungsi Min untuk setiap aturan pada aplikasi fungsi implikasinya.

9. Tahap selanjutnya adalah komposisi aturan. Pada tahap ini digunakan untuk menentukan inferensi dari kumpulan dan korelasi antar aturan menggunakan Metode Max.

10. Kemudian proses defuzzifikasi. Metode yang dipergunakan dalam proses defuzzifikasi ini adalah defuzzifikasi dengan Metode Centroid, Bisector, Means of Maximum (MOM), Largest of Maximum (LOM), dan Smallest of Maximum (SOM).

\section{E. Membangun Sistem}

Pada tahap ini yang dilakukan adalah menerapkan metode Fuzzy-Mamdani untuk menentukan mutu dari buah pepaya California dengan 5 parameter yaitu mayor axis, minor axis, nilai red, nilai green, dan kecacatan (defect) pada buah pepaya California.

\section{F. Implementasi Sistem}

Pada tahap ini sistem sudah dapat mengukur mutu buah pepaya California dengan metode Fuzzy-Mamdani sesuai dengan rancangan. Sistem yang dikembangkan memiliki informasi mengenai buah pepaya California yang akan ditentukan kualitasnya.

\section{G. Evaluasi Sistem}

Pada tahap ini, akan dilakukan evaluasi untuk tingkat akurasi dari kualitas buah pepaya. Untuk menghitung akurasi dapat digunakan Confusion Matrix [15] seperti pada Tabel 1.

Tabel 1. Confusion Matrix [15]

\begin{tabular}{ccc}
\hline \multirow{2}{*}{$\begin{array}{c}\text { Aktual (Hasil } \\
\text { Pakar) }\end{array}$} & \multicolumn{2}{c}{ Classified As (Hasil Sistem) } \\
\cline { 2 - 3 }+ & + & - \\
\hline+ & True Positive (TP) & False Negative (FN) \\
\hline- & False Positive (FP) & True Negative (TN) \\
\hline
\end{tabular}

Perhitungan akurasi dengan tabel confusion matrix adalah sebagai berikut:

$$
\text { Akurasi }=\frac{T P+T N}{T P+F N+F P+T N}
$$

Akurasi dapat didefinisikan sebagai tingkat kedekatan antara nilai prediksi dengan nilai aktual. Presisi didefinisikan sebagai tingkat ketepatan antara informasi yang diminta oleh pengguna dengan jawaban yang diberikan oleh sistem. Rumus presisi adalah: 


$$
\text { Presisi }=\frac{T P}{T P+F P}
$$

Recall didefinisikan sebagai tingkat keberhasilan sistem dalam menemukan kembali sebuah informasi. Recall dihitung dengan rumus:

$$
\text { Recall }=\frac{T P}{T P+F N}
$$

Presisi dan Recall dapat diberi nilai dalam bentuk angka dengan menggunakan perhitungan persentase $(0 \%$ - 100\%) atau dengan menggunakan bilangan antara 0 - 1 . Sistem rekomendasi akan dianggap baik jika nilai presisi dan recallnya tinggi.

\section{Hasil dan Pembahasan}

Setelah dilakukan implementasi dan evaluasi maka didapatkan hasil. Proses evaluasi dilakukan dengan melakukan percobaan menggunakan pepaya untuk dihitung sebagai masukan. Keluaran dari sistem berupa kategori mutu dari pepaya. Pada Tabel 2 menunjukkan data yang diperoleh dari pepaya.

Tabel 2. Data Pepaya yang digunakan

\begin{tabular}{ccccccc}
\hline No & Nama & $\mathrm{R}$ & $\mathrm{G}$ & $\begin{array}{c}\text { Defect } \\
(\%)\end{array}$ & $\begin{array}{c}\text { Mayor } \\
\text { Axis }\end{array}$ & $\begin{array}{c}\text { Minor } \\
\text { Axis }\end{array}$ \\
\hline 1 & pepaya01 & 146 & 170 & 23 & 20 & 9 \\
\hline 2 & pepaya02 & 186 & 171 & 28 & 19 & 9 \\
\hline 3 & pepaya03 & 178 & 185 & 28 & 25 & 12 \\
\hline 4 & pepaya04 & 170 & 148 & 15 & 25 & 12 \\
\hline 5 & pepaya05 & 199 & 175 & 31 & 23 & 11 \\
\hline 6 & pepaya06 & 172 & 186 & 7 & 36 & 23 \\
\hline 7 & pepaya07 & 204 & 152 & 7 & 28 & 18 \\
\hline 8 & pepaya08 & 213 & 166 & 29 & 27 & 16 \\
\hline 9 & pepaya09 & 123 & 137 & 64 & 15 & 8 \\
\hline 10 & pepaya10 & 125 & 128 & 59 & 13 & 7 \\
\hline 11 & pepaya11 & 110 & 121 & 52 & 18 & 10 \\
\hline 12 & pepaya12 & 132 & 135 & 54 & 16 & 9 \\
\hline 13 & pepaya13 & 122 & 134 & 58 & 21 & 11 \\
\hline 14 & pepaya14 & 112 & 113 & 66 & 17 & 9 \\
\hline 15 & pepaya15 & 174 & 187 & 6 & 27 & 11 \\
\hline 16 & pepaya16 & 195 & 160 & 100 & 21 & 9 \\
\hline 17 & pepaya17 & 169 & 180 & 7 & 30 & 14 \\
\hline 18 & pepaya18 & 214 & 192 & 6 & 27 & 13 \\
\hline 19 & pepaya19 & 190 & 187 & 10 & 31 & 15 \\
\hline 20 & pepaya20 & 209 & 185 & 19 & 29 & 13 \\
\hline & & & & & & \\
\hline
\end{tabular}

Pada Tabel 3 merupakan hasil yang didapat dari pakar terkait kualitas pepaya tersebut.

\begin{tabular}{|c|c|c|c|}
\hline No & Nama & Hasil Pakar & Gambar \\
\hline 1 & pepaya01 & Bagus & \\
\hline 2 & pepaya02 & Jelek & \\
\hline 3 & pepaya03 & Bagus & \\
\hline
\end{tabular}

Tabel 3. Hasil Penilaian Pakar

4 pepaya04 Jelek

5 pepaya05 Jelek

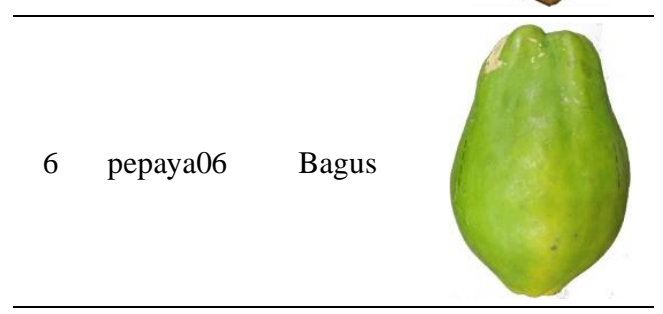

7 pepaya07 Bagus

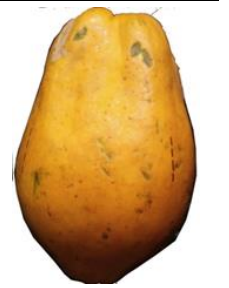




\begin{tabular}{|c|c|c|c|}
\hline No & Nama & Hasil Pakar & Gambar \\
\hline 8 & pepaya08 & Jelek & \\
\hline 9 & pepaya09 & Sedang & \\
\hline 10 & pepaya10 & Jelek & \\
\hline 11 & pepaya11 & Jelek & \\
\hline 12 & pepaya12 & Jelek & \\
\hline 13 & pepaya13 & Sedang & \\
\hline 14 & pepaya14 & Jelek & \\
\hline 15 & pepaya15 & Bagus & \\
\hline
\end{tabular}

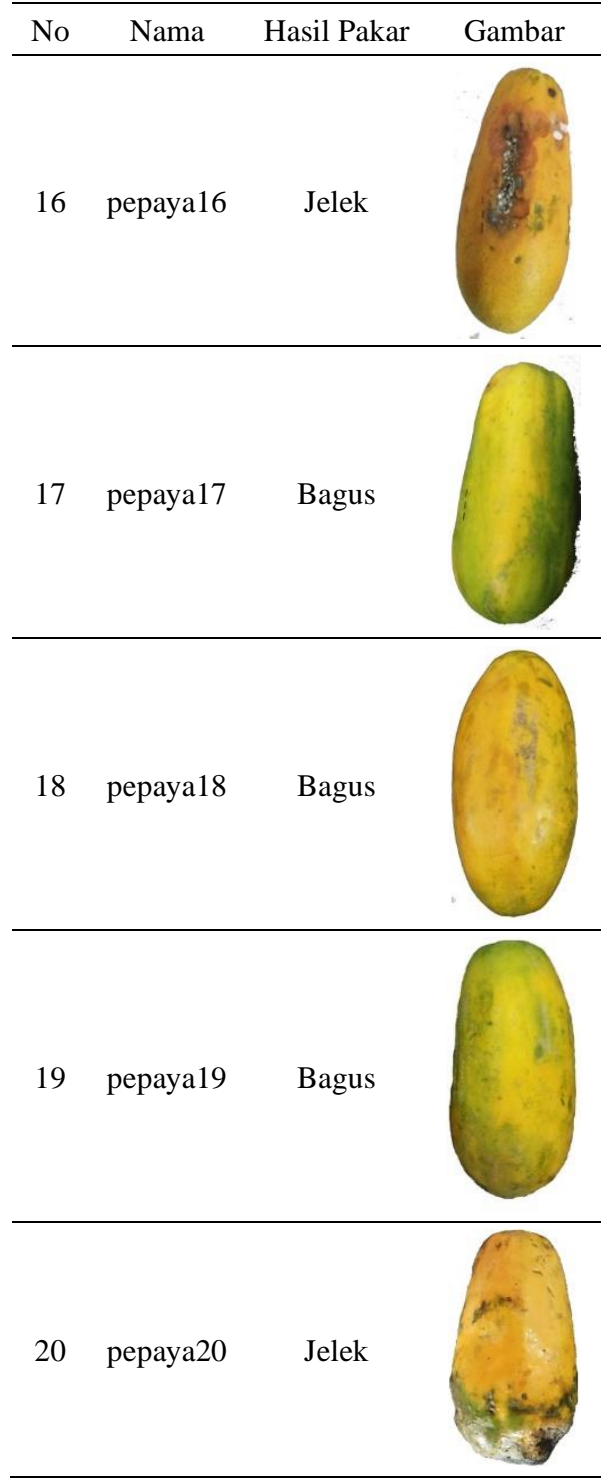

Pada Tabel 4 merupakan perbandingan hasil pakar dan hasil sistem menggunakan metode defuzifikasi Centroid of Area (COA). Terdapat 15 dari 20 pepaya yang diklasifikasikan dengan benar.

Tabel 4. Perbandingan Hasil Pakar dan Hasil Sistem Menggunakan Metode Defuzifikasi COA

\begin{tabular}{ccccc}
\hline No & Nama & COA & Hasil Sistem & Hasil Pakar \\
\hline 1 & pepaya01 & 8,60 & Bagus & Bagus \\
\hline 2 & pepaya02 & 1,38 & Jelek & Jelek \\
\hline 3 & pepaya03 & 1,35 & Jelek & Bagus \\
\hline 4 & pepaya04 & 8,62 & Bagus & Jelek \\
\hline 5 & pepaya05 & 1,23 & Jelek & Jelek \\
\hline 6 & pepaya06 & 8,62 & Bagus & Bagus \\
\hline 7 & pepaya07 & 8,59 & Bagus & Bagus \\
\hline 8 & pepaya08 & 1,26 & Jelek & Jelek \\
\hline 9 & pepaya09 & 1,30 & Jelek & Sedang \\
\hline 10 & pepaya10 & 1,40 & Jelek & Jelek \\
\hline
\end{tabular}




\begin{tabular}{ccccc}
\hline No & Nama & COA & Hasil Sistem & Hasil Pakar \\
\hline 11 & pepaya11 & 1,38 & Jelek & Jelek \\
\hline 12 & pepaya12 & 1,38 & Jelek & Jelek \\
\hline 13 & pepaya13 & 3,28 & Sedang & Sedang \\
\hline 14 & pepaya14 & 1,38 & Jelek & Jelek \\
\hline 15 & pepaya15 & 8,64 & Bagus & Bagus \\
\hline 16 & pepaya16 & 8,62 & Bagus & Jelek \\
\hline 17 & pepaya17 & 8,64 & Bagus & Bagus \\
\hline 18 & pepaya18 & 8,72 & Bagus & Bagus \\
\hline 19 & pepaya19 & 8,64 & Bagus & Bagus \\
\hline 20 & pepaya20 & 8,65 & Bagus & Jelek \\
\hline
\end{tabular}

Pada Tabel 5 merupakan perbandingan hasil pakar dan hasil sistem menggunakan metode defuzifikasi Bisector of Area (BOA). Terdapat 15 dari 20 pepaya yang diklasifikasikan dengan benar.

Tabel 5. Perbandingan Hasil Pakar dan Hasil Sistem Menggunakan Metode Defuzifikasi BOA

\begin{tabular}{ccccc}
\hline No & Nama & BOA & Hasil Sistem & Hasil Pakar \\
\hline 1 & pepaya01 & 8,6 & Bagus & Bagus \\
\hline 2 & pepaya02 & 1,4 & Jelek & Jelek \\
\hline 3 & pepaya03 & 1,3 & Jelek & Bagus \\
\hline 4 & pepaya04 & 8,6 & Bagus & Jelek \\
\hline 5 & pepaya05 & 1,2 & Jelek & Jelek \\
\hline 6 & pepaya06 & 8,6 & Bagus & Bagus \\
\hline 7 & pepaya07 & 8,6 & Bagus & Bagus \\
\hline 8 & pepaya08 & 1,2 & Jelek & Jelek \\
\hline 9 & pepaya09 & 1,3 & Jelek & Sedang \\
\hline 10 & pepaya10 & 1,4 & Jelek & Jelek \\
\hline 11 & pepaya11 & 1,4 & Jelek & Jelek \\
\hline 12 & pepaya12 & 1,4 & Jelek & Jelek \\
\hline 13 & pepaya13 & 3,2 & Sedang & Sedang \\
\hline 14 & pepaya14 & 1,4 & Jelek & Jelek \\
\hline 15 & pepaya15 & 8,6 & Bagus & Bagus \\
\hline 16 & pepaya16 & 8,6 & Bagus & Jelek \\
\hline 17 & pepaya17 & 8,6 & Bagus & Bagus \\
\hline 18 & pepaya18 & 8,7 & Bagus & Bagus \\
\hline 19 & pepaya19 & 8,6 & Bagus & Bagus \\
\hline 20 & pepaya20 & 8,6 & Bagus & Jelek \\
\hline & & & &
\end{tabular}

Pada Tabel 6 merupakan perbandingan hasil pakar dan hasil sistem menggunakan metode defuzifikasi MOM. Terdapat 15 dari 20 pepaya yang diklasifikasikan dengan benar
Tabel 6. Perbandingan Hasil Pakar dan Hasil Sistem Menggunakan Metode Defuzifikasi MOM

\begin{tabular}{ccccc}
\hline No & Nama & MOM & Hasil Sistem & Hasil Pakar \\
\hline 1 & pepaya01 & 8,60 & Bagus & Bagus \\
\hline 2 & pepaya02 & 1,38 & Jelek & Jelek \\
\hline 3 & pepaya03 & 1,35 & Jelek & Bagus \\
\hline 4 & pepaya04 & 8,62 & Bagus & Jelek \\
\hline 5 & pepaya05 & 1,23 & Jelek & Jelek \\
\hline 6 & pepaya06 & 8,62 & Bagus & Bagus \\
\hline 7 & pepaya07 & 8,59 & Bagus & Bagus \\
\hline 8 & pepaya08 & 1,26 & Jelek & Jelek \\
\hline 9 & pepaya09 & 1,30 & Jelek & Sedang \\
\hline 10 & pepaya10 & 1,40 & Jelek & Jelek \\
\hline 11 & pepaya11 & 1,38 & Jelek & Jelek \\
\hline 12 & pepaya12 & 1,38 & Jelek & Jelek \\
\hline 13 & pepaya13 & 3,28 & Sedang & Sedang \\
\hline 14 & pepaya14 & 1,38 & Jelek & Jelek \\
\hline 15 & pepaya15 & 8,64 & Bagus & Bagus \\
\hline 16 & pepaya16 & 8,7 & Bagus & Jelek \\
\hline 17 & pepaya17 & 8,75 & Bagus & Bagus \\
\hline 18 & pepaya18 & 8,95 & Bagus & Bagus \\
\hline 19 & pepaya19 & 8,75 & Bagus & Bagus \\
\hline 20 & pepaya20 & 8,75 & Bagus & Jelek \\
\hline & & & &
\end{tabular}

Pada Tabel 7 merupakan perbandingan hasil pakar dan hasil sistem menggunakan metode defuzifikasi LOM. Terdapat 14 dari 20 pepaya yang diklasifikasikan dengan benar.

Tabel 7. Perbandingan Hasil Pakar dan Hasil Sistem Menggunakan Metode Defuzifikasi LOM

\begin{tabular}{ccccc}
\hline No & Nama & LOM & Hasil Sistem & Hasil Pakar \\
\hline 1 & pepaya01 & 10 & Bagus & Bagus \\
\hline 2 & pepaya02 & 2,5 & Jelek & Jelek \\
\hline 3 & pepaya03 & 2,5 & Jelek & Bagus \\
\hline 4 & pepaya04 & 10 & Bagus & Jelek \\
\hline 5 & pepaya05 & 1,9 & Jelek & Jelek \\
\hline 6 & pepaya06 & 10 & Bagus & Bagus \\
\hline 7 & pepaya07 & 10 & Bagus & Bagus \\
\hline 8 & pepaya08 & 2 & Jelek & Jelek \\
\hline 9 & pepaya09 & 2,2 & Jelek & Sedang \\
\hline 10 & pepaya10 & 2,6 & Jelek & Jelek \\
\hline 11 & pepaya11 & 2,5 & Jelek & Jelek \\
\hline 12 & pepaya12 & 2,5 & Jelek & Jelek \\
\hline 13 & pepaya13 & 2,7 & Jelek & Sedang \\
\hline 14 & pepaya14 & 2,5 & Jelek & Jelek \\
\hline 15 & pepaya15 & 10 & Bagus & Bagus \\
\hline & & & &
\end{tabular}




\begin{tabular}{ccccc}
\hline No & Nama & LOM & Hasil Sistem & Hasil Pakar \\
\hline 16 & pepaya16 & 10 & Bagus & Jelek \\
\hline 17 & pepaya17 & 10 & Bagus & Bagus \\
\hline 18 & pepaya18 & 10 & Bagus & Bagus \\
\hline 19 & pepaya19 & 10 & Bagus & Bagus \\
\hline 20 & pepaya20 & 10 & Bagus & Jelek \\
\hline
\end{tabular}

Pada Tabel 8 merupakan perbandingan hasil pakar dan hasil sistem menggunakan metode defuzifikasi SOM. Terdapat 14 dari 20 pepaya yang diklasifikasikan dengan benar.

Tabel 8. Perbandingan Hasil Pakar dan Hasil Sistem Menggunakan Metode Defuzifikasi SOM

\begin{tabular}{ccccc}
\hline No & Nama & SOM & Hasil Sistem & Hasil Pakar \\
\hline 1 & pepaya01 & 7,4 & Bagus & Bagus \\
\hline 2 & pepaya02 & 0 & Jelek & Jelek \\
\hline 3 & pepaya03 & 0 & Jelek & Bagus \\
\hline 4 & pepaya04 & 7,4 & Bagus & Jelek \\
\hline 5 & pepaya05 & 0 & Jelek & Jelek \\
\hline 6 & pepaya06 & 7,4 & Bagus & Bagus \\
\hline 7 & pepaya07 & 7,3 & Bagus & Bagus \\
\hline 8 & pepaya08 & 0 & Jelek & Jelek \\
\hline 9 & pepaya09 & 0 & Jelek & Sedang \\
\hline 10 & pepaya10 & 0 & Jelek & Jelek \\
\hline 11 & pepaya11 & 0 & Jelek & Jelek \\
\hline 12 & pepaya12 & 0 & Jelek & Jelek \\
\hline 13 & pepaya13 & 0 & Jelek & Sedang \\
\hline 14 & pepaya14 & 0 & Bagus & Jelek \\
\hline 15 & pepaya15 & 7,5 & Bagus & Bagus \\
\hline 16 & pepaya16 & 7,4 & Bagus & Jelek \\
\hline 17 & pepaya17 & 7,5 & Bagus & Bagus \\
\hline 18 & pepaya18 & 7,9 & Bagus & Bagus \\
\hline 19 & pepaya19 & 7,5 & Bagus & Bagus \\
\hline 20 & pepaya20 & 7,5 & Jelek & Jelek \\
\hline & & & & \\
\hline
\end{tabular}

Kemudian dilakukan perhitungan untuk mendapatkan tingkat akurasi penentuan kualitas terhadap data uji menggunakan Confusion Matrix seperti Tabel 9, Tabel 10, Tabel 11, Tabel 12 dan Tabel 13.

Pada Tabel 9 merupakan confusion matrix untuk metode defuzifikasi menggunakan COA. Pada Tabel 9 dapat dillihat bahwa rata-rata akurasi $83 \%$. Akurasi untuk jelek $75 \%$, akurasi untuk sedang $95 \%$ dan akurasi untuk bagus $80 \%$.
Tabel 9. Hasil Confusion Matrix Metode Defuzifikasi COA

\begin{tabular}{|c|c|c|c|c|c|c|c|}
\hline & $\mathrm{TP}$ & FP & $\mathrm{FN}$ & $\mathrm{TN}$ & $A c c$ & $P$ & $R$ \\
\hline Jelek & 7 & 2 & 3 & 8 & 75 & 78 & 70 \\
\hline Sedang & 1 & 0 & 1 & 18 & 95 & 100 & 50 \\
\hline Bagus & 7 & 3 & 1 & 9 & 80 & 70 & 88 \\
\hline \multicolumn{5}{|c|}{ Rata-rata } & 83 & 83 & 69 \\
\hline
\end{tabular}

Pada Tabel 10 merupakan confusion matrix untuk metode defuzifikasi menggunakan BOA. Pada Tabel 10 dapat dillihat bahwa rata-rata akurasi $83 \%$. Akurasi untuk jelek $75 \%$, akurasi untuk sedang $95 \%$ dan akurasi untuk bagus $80 \%$.

Tabel 10. Hasil Confusion Matrix Metode Defuzifikasi BOA

\begin{tabular}{|c|c|c|c|c|c|c|c|}
\hline & TP & FP & $\mathrm{FN}$ & $\mathrm{TN}$ & $A c c$ & $P$ & $R$ \\
\hline Jelek & 7 & 2 & 3 & 8 & 75 & 78 & 70 \\
\hline Sedang & 1 & 0 & 1 & 18 & 95 & 100 & 50 \\
\hline Bagus & 7 & 3 & 1 & 9 & 80 & 70 & 88 \\
\hline \multicolumn{5}{|c|}{ Rata-rata } & 83 & 83 & 69 \\
\hline
\end{tabular}

Pada Tabel 11 merupakan confusion matrix untuk metode defuzifikasi menggunakan MOM. Pada Tabel 11 dapat dillihat bahwa rata-rata akurasi $82 \%$. Akurasi untuk jelek $70 \%$, akurasi untuk sedang $95 \%$ dan akurasi untuk bagus $80 \%$.

Tabel 11. Hasil Confusion Matrix Metode Defuzifikasi MOM

\begin{tabular}{|c|c|c|c|c|c|c|c|}
\hline & $\mathrm{TP}$ & FP & $\mathrm{FN}$ & $\mathrm{TN}$ & $A c c$ & $P$ & $R$ \\
\hline Jelek & 7 & 3 & 3 & 7 & 70 & 70 & 70 \\
\hline Sedang & 1 & 1 & 0 & 18 & 95 & 50 & 0 \\
\hline Bagus & 7 & 3 & 1 & 9 & 80 & 70 & 88 \\
\hline \multicolumn{5}{|c|}{ Rata-rata } & 82 & 63 & 53 \\
\hline
\end{tabular}

Pada Tabel 12 merupakan confusion matrix untuk metode defuzifikasi menggunakan LOM. Pada Tabel 12 dapat dillihat bahwa rata-rata akurasi $80 \%$. Akurasi untuk jelek $70 \%$, akurasi untuk sedang $90 \%$ dan akurasi untuk bagus $80 \%$.

Tabel 12. Hasil Confusion Matrix Metode Defuzifikasi LOM

\begin{tabular}{|c|c|c|c|c|c|c|c|}
\hline & TP & FP & $\mathrm{FN}$ & $\mathrm{TN}$ & $A c c$ & $P$ & $R$ \\
\hline Jelek & 7 & 3 & 3 & 7 & 70 & 70 & 70 \\
\hline Sedang & 0 & 0 & 2 & 18 & 90 & 0 & 0 \\
\hline Bagus & 7 & 3 & 1 & 9 & 80 & 70 & 88 \\
\hline \multicolumn{5}{|c|}{ Rata-rata } & 80 & 47 & 53 \\
\hline
\end{tabular}

Pada Tabel 13 merupakan confusion matrix untuk metode defuzifikasi menggunakan SOM. Pada Tabel 13 dapat dillihat bahwa rata-rata akurasi $80 \%$. Akurasi untuk jelek $70 \%$, akurasi untuk sedang $90 \%$ dan akurasi untuk bagus $80 \%$. 
Tabel 13. Hasil Confusion Matrix Metode Defuzifikasi SOM

\begin{tabular}{|c|c|c|c|c|c|c|c|}
\hline & $\mathrm{TP}$ & FP & FN & $\mathrm{TN}$ & $A c c$ & $P$ & $R$ \\
\hline Jelek & 7 & 3 & 3 & 7 & 70 & 70 & 70 \\
\hline Sedang & 0 & 0 & 2 & 18 & 90 & 0 & 0 \\
\hline Bagus & 7 & 3 & 1 & 9 & 80 & 70 & 88 \\
\hline \multicolumn{5}{|c|}{ Rata-rata } & 80 & 47 & 53 \\
\hline
\end{tabular}

\section{Kesimpulan}

Akurasi tertinggi yang didapat yaitu $75 \%$ dengan menggunakan metode defuzifikasi Centroid, Bisector dan MOM. Metode defuzifikasi LOM dan SOM memberikan hasil sebesar 70\%. Dengan menggunakan confusion matrix dapat dilihat bahwa akurasi secara rata-rata $80 \%$ sampai $83 \%$.

\section{DAFTar Pustaka}

[1] B. A. Bakar and R. Ratnawati, "Petunjuk Teknis Budidaya Pepaya," Balai Pengkaj. Teknol. Pertan. Aceh, p. 35, 2017.

[2] S. N. Usmayani, E. Basuki, and I. W. S. Yasa, "PENGGUNAAN KALIUM PERMANGANAT (KMnO 4 ) PADA PENYIMPANAN BUAH PEPAYA CALIFORNIA (Carica papaya L.) [The Use of Potassium Permanganate (KMnO 4 ) On Shelf Life of California's Papaya (Carica papaya L.)]," J. Ilmu dan Teknol. Pangan), vol. 1, no. 2, pp. 48-55, 2015.

[3] T. Sutojo, E. Mulyanto, and V. Suhartono, Kecerdasan Buatan. Yogyakarta: Andi Offset, 2011.

[4] P. N. Andono and T. Sutojo, Pengolahan citra digital. Penerbit Andi, 2017.

[5] S. A. Syakry, M. Mulyadi, and Z. K. Simbolon, "Buah Menggunakan Fuzzy C-Means ( Fcm ) Clustering," $J$. Penelit. Tek. Inform., vol. 7, no. 2, pp. 150-169, 2015, doi: https://doi.org/10.29103/techsi.v7i2.199.

[6] S. S. A. Syakry and M. Mulyadi, "Analisis Tingkat Kandungan Nilai Warna untuk Penentuan Tingkat Kematangan pada Citra Buah Papaya callina," J. Ilm. Elit. ELEKTRO, vol. 4, pp. 31-37, 2013.

[7] N. Febriany, F. Agustina, and R. Marwati, "Aplikasi Metode Fuzzy Mamdani Dalam Penentuan Status Gizi Dan Menggunakan Software Matlab," J. EurekaMatika, vol. 5, no. 1, pp. 84-96, 2017.

[8] B. Fechera, J. Kustija, and S. Elvyanti, "Optimasi Penggunaan Membership Function Logika Fuzzy Pada Kasus Identifikasi Kualitas Minyak Transformator.," ELECTRANS, vol. 204, no. 2, pp. 27-35, 2012.

[9] R. Munarto, E. Permata, and R. Salsabilla, "Klasifikasi Kualitas Biji Jagung Manis Berdasarkan Fitur Warna Menggunakan Fuzzy Logic,” Simp. Nas. RAPI XIII - 2014 FT UMS, pp. 5-12, 2014.

[10] J. Nasir and J. Suprianto, "Analisis Fuzzy Logic Menentukan Pemilihan Motor Honda dengan Metode Mamdani," J. Edik Inform., vol. 3, no. 2, pp. 177-187, 2017, doi: 10.22202/jei.2017.v3i2.1962.

[11] S. N. Budiman and H. Tjandrasa, "Sistem Pengukuran
Mutu Buah Mangga Berdasarkan Kematangan, Ukuran dan Area Bercak Menggunakan Fuzzy Inference System," Inspir. J. Teknol. Inf. dan Komun., vol. 7, no. 1, pp. 1020, 2017, doi: 10.35585/inspir.v7i1.2432.

[12] R. Pandey, N. Gamit, and S. Naik, "A novel nondestructive grading method for Mango (Mangifera Indica L.) using fuzzy expert system," in 2014 International Conference on Advances in Computing, Communications and Informatics (ICACCI), 2014, pp. 1087-1094, doi: 10.1109/ICACCI.2014.6968366.

[13] A. Wirawan and A. Azhari, "Implementasi Metode FuzzyMamdani untuk Menentukan Jenis Ikan Konsumsi Air Tawar Berdasarkan Karakteristik Lahan Budidaya Perikanan,” Bimipa, vol. 24, no. 1, pp. 29-38, 2014.

[14] F. Y. Mulato, "KLASIFIKASI KEMATANGAN BUAH JAMBU BIJI MERAH ( Psidium Guajava ) DENGAN MENGGUNAKAN MODEL FUZZY," Universitas Negeri Yogyakarta, 2015.

[15] H. Jiawei, M. Kamber, and J. Pei, Data Mining: Concepts and Techniques. Morgan Kaufmann, 2011. 